 \\ z Filologii Polskiej i Słowiańskiej
}

\author{
Євгенія Анатоліївна Карпіловська \\ (Інститут української мови НАН України, Київ)
}

\section{Роль картотеки «портретів слів» в укладанні словників нового покоління}

Картотека традиційно пов’язана з укладанням словників як їхня фактографічна база. Класична - цитатна - картотека зорієнтована переважно на фіксацію вживання в тексті слова або його окремої форми. Так, наприклад, будувалася картотека для укладання українських академічних словників, зокрема найавторитетнішого з них - тлумачного «Словника української мови» в 11-ти томах, виданого протягом 1970-1980 pр. (СУМ-11, 1970-1980). Поява комп’ютера, потужного й оперативного засобу збирання, опрацювання, збереження й передавання відомостей про мову, кардинально змінила технологію словникарської праці, середовище її здійснення й форму представлення її продуктів. Ці зміни заторкнули всі ланки усталеного процесу укладання словника, а саме: 1) текст як картину реального функціонування словникового складу мови, 2) картотеку як результат лексикографічного опрацювання вживань слів у конкретних текстах та 3) словник як цілісну модель лексичної системи мови на певному етапі ії побутування. До кожного із членів традиційного

This is an Open Access article distributed under the terms of the Creative Commons Attribution 3.0 PL License (creativecommons.org/licenses/by/3.0/pl/), which permits redistribution, commercial and non-commercial, provided that the article is properly cited. () The Author(s) 2017.

Publisher: Institute of Slavic Studies, Polish Academy of Sciences

[Wydawca: Instytut Slawistyki Polskiej Akademii Nauk] 
ланцюжка текст - картотека - словник додалося означення електронний або комп'ютерний.

Із розвитком комп'ютерних технологій до традиційного тричленного ланцюжка створення словника додався четвертий складник - корпус. Корпус на сьогодні розуміють як базу текстів, розмічених для надання його користувачам інформації про формальні, семантичні й функціональні властивості слова, базу, збалансовану й показову для реального стану системи мови в певний період іiї існування, як взірець «мови в дії». Обсяг корпусу, спектр уміщуваних текстів та розмітка на різних рівнях їхньої структурної організації мають забезпечити його надійність для відображення в словнику лексичної системи мови. Однак, як засвідчує вже понад півстолітня практика створення корпусів мов, корпус як сукупність текстів, дібраних за певними параметрами, призначених для виконання певних запитів користувачів, аж ніяк не може претендувати на повноту картини мови, відбиття її динаміки, змін у ній, яким би потужним він не був. Більше того, розмітка корпусу (морфологічна, синтаксична, семантична) унаочнює вже наявні знання про мову, а отже, не передбачає виявлення в ній нових явищ. Таке знання користувач уже повинен мати, створюючи певний запит для пошуку інформації про слово в корпусі. Не маючи відповідних орієнтирів для пошуку, користувач, зокрема й лексикограф, починає обертатися в зачарованому колі вже відомого знання про мову.

С. Лендау слушно нагадував лексикографам, що «корпус завжди $€$ добіркою й може репрезентувати лише мовлення та письмо дібраних транскрипцій та текстів» (Лендау, 2012, с. 316). I ще одне не менш важливе застереження С. Лендау у зв’язку з використанням корпусів для укладання нових словників: «Із дальшим більшанням корпусів лексикографам у прийманні рішень щодо частотності та форми доведеться дедалі більше покладатися на програмові інструменти. Так само їм доведеться покладатися на те, що софт точно реагує на їхні пошуки, що їх доведеться задавати вужче, ніж тепер. Усі словники роблено за суворих часових обмежень. Ніхто не матиме часу сортувати тисячі чи навіть багато сотень тисяч фіксацій, аби знайти конкретний слововжиток, що його треба подати в словнику» (Лендау, 2012, с. 316). Докази цих слушних міркувань авторитетного американського лексикографа подають численні словники, укладені й видані з використанням новітніх комп'ютерних технологій опрацювання мови. Доводиться визнати, що новизна форми 
в них беззастережно домінує над новизною змісту. У зв'язку із цим дедалі актуальнішим стає питання про можливості використання корпусу в укладанні словників нового покоління, зумовлені самим типом цього нового інструменту роботи лексикографа. Це питання тягне за собою й не менш актуальне питання про те, які інструменти можуть доповнити й підтримати корпус, подавши інші можливості для видобування знання про слово з текстів, усунувши обмеження, спричинені як добором текстів у корпусі, так і їхньою розміткою в ньому. Пошуки відповідей на ці питання приводять до усвідомлення необхідності паралельно 3 творенням і розбудовою корпусів мови формувати й нові лексичні картотеки як бази узагальнення спостережень над змінами слів у текстах, над мобільними ділянками лексикону мови. Отже, поява корпусів не заперечила важливості картотек для нових технологій укладання словників, а посилила їхню роль і висунула до них нові вимоги.

Сучасна картотека має передусім відстежувати зміни в мові, причому, не лише появу інновацій, а й зміни властивостей уже наявної лексики. Зосереджу увагу на лексиці, оскільки слово як базова одиниця слов'янської номінації упрозорює зміни на всіх рівнях мовної системи: від фонемної й графемної до семантичної й стилістичної підсистем. Необхідність підтримки корпусу додатковими інструментами для праці лексикографа підтверджує сучасна практика укладання словників, за умови, звичайно, що їхні автори прагнуть укласти словник, новий і за формою, і за змістом. Зауважу, що це твердження повною мірою стосується не лише корпусозорієнтованих лексикографічних технологій, а й технологій мереже-, або інтернетозорієнтованих. Останні також потребують створення збалансованого, показового корпусу інтернетресурсів, взірця, еталону функціонування слова в інтернет-комунікації.

Корпус стає надійним «полігоном» для перевірки мовної практики лише у взаємодії з картотекою, створеною внаслідок професійного мовознавчого аналізу сучасної мовної практики, яку відбивають сучасні тексти широкого стильового й тематичного спектру. Картотека дає користувачеві нові орієнтири для пошуку в корпусі й водночас виявляє можливості для його розбудови. Саме за умови такої взаємодії можна погодитися з твердженням, що сучасна лінгвістика, а в їі рамах і лексикографія, $€$ лінгвістикою корпусів. Один з фундаторів Національного корпусу російської мови Володимир Плунгян стверджує, що «корпус дозволяє нам зрозуміти, якою є мова насправді, а не якою ми хочемо, щоб вона була», 
і на цій підставі робить висновок: «Більше того, і словники, і граматики тепер потрібні не традиційні, а нового покоління, тобто не просто словники та граматики, а словники такого-то корпусу і граматики такого-то корпусу, що відразу дає нам змогу їх перевірити» (Плунгян, 2009).

Свого часу Ю. М. Караулов інтенсивний процес «ословникування» сучасної інтелектуальної діяльності, зокрема мовознавчої, пояснив тим, що «словник стає метою й підсумком дослідницької праці над тією чи іншою проблемою, ніби «відповіддю» на певне лінгвістичне завдання» (Караулов, 1981, с. 42). Словники 3 огляду на таке зростання їхньої ролі в діяльності суспільства й стали одним з провідних і показових об’єктів застосування новітніх комп'ютерних технологій опрацювання інформації, зокрема корпусних. Вони ж завдяки цьому й унаявнюють сьогодні переваги й недоліки таких технологій, передусім, на моє глибоке переконання, пов’язаних із можливостями, які вони створюють для швидкісного укладання словника.

Досвід роботи з корпусами доводить необхідність не лише їхнього стильового розшарування, деталізації їхньої розмітки й розбудови їхніх інтерфейсів, а й формування поруч із фундаментальними, національними корпусами мови широкого спектру пошукових, дослідницьких корпусів, зорієнтованих на виконання певних запитів користувачів і певних типів дослідницьких завдань, зокрема на укладання словників конкретних типів. Наприклад, автори академічного електронного «Великого словника польської мови», створюваного в Інституті польської мови ПАН («Wielki słownik języka polskiego»), як основне джерело для його творення обрали Національний корпус польської мови (Narodowy Korpus Języka Polskiego (NKJP)). Як друге за важливістю джерело добору й перевірки мовного матеріалу вони формують «допоміжний корпус, створений в ІПМ ПАН (IJP PAN) спеціально для потреб словника, який уміщує тексти, що з різних причин не ввійшли (і не ввійдуть) до NKJP» (WSJP). Третім джерелом $\epsilon$ ресурси польського Інтернету. Крім того, оскільки автори прагнуть якнайбільше використати досягнення польського мовознавства ХХ століття, зокрема в аспекті семантичного, словозмінного, синтаксичного описів лексичних одиниць, то до створення нового словника залучено й наявні кращі словники польської мови. Так, визначення відповідності лексем чинним мовним нормам та їхніх стилістичних кваліфікаторів укладачі WSJP здійснюють за «Великим словником правильної польської мови» ПВН (Wielki słownik poprawnej polszczyzny PWN). 
Ідею неологічної служби мови як динамічної й багатофункціональної електронної бази розвивають російські лексикографи - працівники Інституту лінгвістичних досліджень РАН у Санкт-Петербурзі. В обгрунтуванні цієї ідеї приваблюють широкі можливості пошуку в електронних версіях уже наявних словників, які надаватиме користувачеві навігаційне меню такої служби. Останнє уможливлюватиме таке: перевірку наявності в них певної лексеми, одержання інформації про її значення, написання й наявність варіантів, групування лексики за частиномовним принципом, родом, спільним словотвірним елементом, семантичною, тематичною, функціонально-стилістичною, хронологічною ознаками, виділення іншомовної лексики, створення індексів зі зворотним алфавітом тощо (Буцева, 2013, с. 97).

Як доводить досвід укладання нових українських словників, зокрема академічного тлумачного «Словника української мови» в 20-ти томах (на сьогодні видано вже 6-ий його том (Згага-Кварта)), їм бракує перевіреного, системно оновленого лексичного ресурсу. СУМ-20 (2010) доводить, що для його укладання як насправді нового тлумачного словника української мови явно недостатньо бази, окресленої в передмові до його першого тому: електронної версії попереднього СУМ-11, корпусу текстів, про показовість і збалансованість якого судити важко, оскільки його не удоступнено для широкого користування, й ресурсів українського Інтернету (СУМ-20 I, 2010, с. 7). На це вказують і мовознавці (Німчук, 2012), і користувачі словника, зокрема українські письменники (Пилипчук, 2012). Ідеться не лише про повноту подання в реєстрі нового тлумачного словника раніше не зафіксованої лексики як власне нової, так і такої, що з різних причин залишилася поза реєстрами нормативних загальномовних словників. Не менш важливим завданням $є$ перевірка активності такої лексики в сучасній мовній практиці, як і встановлення за сучасними текстами властивостей лексики, зафіксованої в попередніх українських словниках.

Лексикографи сьогодні, як ніколи, потребують надійних орієнтирів для перевірки нових і вже відомих ресурсів словників на показових корпусах, указівки на те, що саме слід у них шукати й перевіряти. Такі орієнтири й має подати електронна картотека нового типу - динамічна, багатофункціональна база даних про зміни в складі, формі, змісті та функціонуванні слів. Різновидом такого інструменту лексикографів, який підтримував би й доповнював корпус мови, може бути картотека 
«портретів слів». Концепцію такої картотеки для створення українських словників нового покоління було запропоновано на початку XXI ст. (Карпіловська, 2004) і втілено у форматах опрацювання нової лексики в Компютерному фонді інновацій в українській мові (далі - КФІ) Інституту української мови НАН України в Києві. Зразки опрацювання за матеріалами такої електронної картотеки лексичних інновацій різних типів - новотворів, актуалізованої лексики, неосемантизмів та новозапозичень - оприлюднено в ідеографічному словнику нової лексики «Активні ресурси сучасної української номінації» (АРСУН, 2013). Ідея такої картотеки виросла з необхідності опрацювання нової лексики для українських словників нового покоління, причому для словників саме активного типу, що відображали б реальний стан мови й відповідали 6 на реальні потреби та запити мовної практики сучасного українського суспільства.

«Портрет слова» в сучасній лексикографії трактують по-різному. Наприклад, розробники NKJP визначають його як спектр уживань слова в текстах різних стилів. У КФІ «портрет слова» формується як сукупність його не лише текстових, а й системних властивостей. У форматах нашої картотеки для моделювання «портрета» слова запропоновано 7 зон інформації: 1) зона слова - об'єкта опису із зазначенням можливих варіантів написання чи наголошування, зі вказівкою на тип такої лексеми (актуалізоване слово, новозапозичення, новотвір чи неосемантизм), а також хронології її побутування в українській мові за матеріалами словників і текстів, починаючи від перших їі фіксацій; 2) зона відмінювання слова (за «Граматичним словником української літературної мови. Словозміна» [ГС, 2011]). У цій зоні для слів, зареєстрованих у словниках до 1991 р., тобто року проголошення незалежності України й утвердження української мови в статусі мови держави, подано зразок відмінювання (код словозмінної парадигми в ГС) або зазначено, що вони невідмінювані, а для нових слів, відсутніх у реєстрі ГС (його обсяг, утім, досить поважний - близько 140 тис. слів), за наявними в ньому зразками словозміни визначено парадигму їхнього відмінювання з можливими її варіантами; 3) і 4) зони дефініцій слова, відповідно, нової і старої (поданої у словниках до 1991 р.) для унаявнення так званих неосемантизмів, тобто нових значень уже відомих слів на зразок слова вертикаль, що навіть у новому однотомному академічному «Словнику української мови», виданому 2012 р. (СУМ-1, 2012), витлумачено як суто математичний термін, хоча в текстах його вже давно вживають 
зі значенням 'ієрархія, система підпорядкованих об’єктів’, наприклад, виконавча вертикаль, організація із суворою вертикаллю; 5) зона синтагматики (сполучуваності) слова, що засвідчує предикацію, текстові властивості слова; у цій зоні з різним ступенем деталізації можна фіксувати типи словосполук з описуваним словом, підкреслюючи передусім нові його сполучувальні властивості, зокрема внаслідок міжчастиномовних переходів (конверсіі) або неосемантизації; 6) зона парадигматики слова, його системні властивості, відношення з іншими словами: синонімічні, антонімічні (градуйовані мезонімами, порівн. у новому значенні 'законний’ тріаду прикметників білиц̆ - сірици - чорний (зарплата, ринок, товари) або опозиції на зразок науковиц - білянауковий, навколонауковий, квазінауковий, лженауковий, псевдонауковий - ненауковий, антинауковий, омонімічні, порівн. інновацію альтернативник у значеннях 'особа, яка перебуває на альтернативній військовій службі', 'особа з альтернативною, нетрадиційною сексуальною орієнтацією' і 'представник альтернативних галузей наукового знання або мистецтва (історії, літератури, музики, кінематографу)', гіперо-гіпонімічні (родо-видові, категорійно-розрядні) відношення, наприклад, між словами мережа та I(i)нтернет у їхньому новому значенні 'об'єднання комп'ютерів'; 7) зона епідигматики (словотворення) слова, що охоплює всі способи морфологічного й семантичного словотворення, реалізовані таким словом у сучасних текстах, зокрема каламбурне словотворення, різноманітну гру з ним на зразок $3 \mathrm{MIŭ}$. $3 \mathrm{MIcm}$ на базі абревіатури $3 M I$ ‘Засоби Масової Інформації. Остання зона дуже важлива для української мови, оскільки словотворення втримує свої позиції провідного способу її номінації і захищає її основну типологічну рису - синтетизм, однослівність позначень.

Зібраний у такій картотеці матеріал дає змогу виділяти ті слова, що виявляють у сучасному українському лексиконі тяжіння як до активізації, так і до пасивізації, а отже, складають його мобільні ділянки й тому потребують пильної уваги лексикографів. Відомості, накопичувані в нашій картотеці вже протягом 10 років за аналізом текстів різних функціональних стилів - публіцистичного, наукового, зокрема науково-популярного, офіційно-ділового, художнього, за мовою українських мас-медій та Інтернету, уможливлюють створення орієнтирів для відстежування ситуації на мобільних ділянках сучасного українського лексикону, передусім для перевірки активності й ступеня усталення в ньому різного типу інновацій та ознак нового життя пасивізованої лексики, зокрема 
радянізмів. Останні, за свідченнями текстів початку XXI ст., зазнають нейтралізації, розширення свого значення, як, наприклад, слово партія, або набувають іронічного, експресивно-оцінного ореолу. Так, слово стахановець, що в радянський час мало значення 'новатор, передовик соціалістичного виробництва, учасник масового руху трудящих за підвищення продуктивності праці на основі оволодіння новою технікою (у 30-40-х роках)' [СУМ-11 IX, 1970-1980, с. 672], утворене від прізвища радянського шахтаря Олексія Стаханова, нині можна зустріти в таких контекстах уживання, далеких від радянської дійсності: Ще раз про «стахановців» на ринку (про стан американського фондового ринку www.finance.ua, 20.01.2012). Двоспрямований зв'язок тексту, корпусу як сукупності текстів-еталонів і картотеки «портретів слів» як їхнього професійного осмислення, «лабораторії лексикографа» та «полігону» для прийняття певних його рішень щодо подання в словнику того чи іншого слова має забезпечити надійність моделювання в українських словниках нового покоління реального побутування мови, подати для цього перевірений лексичний ресурс.

Такий різноаспектний «портрет» слова, звичайно ж, варто формувати не лише для нової або оновлюваної лексики, а й для лексики, стабільно відтворюваної в українських текстах різних функціональних стилів, сталої в складі українського лексикону. Стабільне ядро словникового складу української мови, функціонуючи в мовній діяльності сучасного суспільства, також неминуче, з одного боку, виявляє рухливість, змінюваність своїх властивостей, наприклад, у сфері словозміни й словотворення, а з другого, укладання нових словників неможливе без подання такого ядра, оскільки вони мають загалом відобразити реальну картину функціонування мови, зокрема як її стабільного ядра, так і її мобільної периферії з перехідною зоною між ними, що, своєю чергою, становить особливо цікаве для лексикографа накопичення змін у словниковому фонді мови.

Зорієнтування лише на текст або лише на корпус не дає лексикографу змоги виявити нове знання про мову в його надійній повноті й доказовості. Корпус може взагалі не давати відповіді на запит користувача щодо конкретного слова, словоформи чи словосполуки. I тоді постає питання про відображення в ньому певного різновиду мовної практики та її продуктів - текстів певної тематики й призначення. Наприклад, як засвідчує наш КФІ, в останні десятиліття в українській мові в кінцевій 
позиції композитів активно функціонує аброоснова -мат (від слова автомат). Деякі з таких композитів-новотворів (банкомат, паркомam) зареєстрував СУМ-1 (2012). Проте в ньому немає інших подібних композитів, активних у певних сферах сучасної українськомовної практики, зокрема ігромат, музикомат або музомат. Не засвідчені ці лексеми й у Корпусі текстів української мови (КТУМ, n.d.), створеному колективом співробітників лабораторії комп'ютерної лінгвістики Київського національного університету ім. Т. Шевченка під керівництвом Н. П. Дарчук (Дарчук, 2013). Він налічує на сьогодні близько 70 млн. слововживань, має морфологічну та синтаксичну розмітку й виставлений для вільного користування в Інтернеті на лінгвістичному порталі www.mova.info. Натомість і мас-медії, і строката українськомовна інтернеткомунікація засвідчують не лише наявність вищезгаданих композитів у сучасній мові, а й їхнє конкурування з аналітичними номінаціями, як-от: музичниц̆ автомат, гральний автомат, ігровий автомат, порівн. у газетній статті: В одному з ресторанів Сан-Дієго двоє зловмисників викрали музичний автомат, сплутавщи його з банкоматом (Високий замок, 04.03.2013) і в рекламних оголошеннях на сайтах розважальних закладів: Музичні та гральні автомати (для кав'ярень, барів, ресторанів, гральних залів) від підприємства-виробника, ...музомат для замовлення не тільки музики, а також кліпів і мультбільмів, ...зарядив у музикомат аж 50 гривень і замовив иілу купу музики; Пакет "Ігромат»: способи обману і секрети ігрових автоматів. Ці приклади доводять необхідність спостереження за вживанням таких конкурентних позначень для з'ясування їхніх ролі та місця в мовній практиці, закріплення за певними її сферами. Бачу сенс залучити для цього картотеку «портретів слів» у їі взаємодії із сучасними текстами. Доведення стійкості номінацій-композитів протягом, принаймні, десяти років покаже, чи справді треба доповнити корпус мови відповідними текстами. Десять років, як довели праці дослідників динаміки слов'янських мов, слугують надійним часовим відтинком для встановлення стабільності інновацій. Н. З. Котелова свого часу запропонувала до словників-довідників нової лексики вводити такі неологізми, які стабільно функціонують у текстах протягом 3-4 років, а для контролю обстежувати тексти перших і останніх двох років обраного десятиліття (Котелова, 1984, с. 5).

Комп’ютерні технології уможливили щорічну перевірку текстів на відміну від методики Н. З. Котелової, розрахованої на їхнє обстеження 
вручну. Наприклад, німецькі лексикографи У. Квастхоф, С. Лібольд, Н. Тауберт і Т. Вольф - укладачі «Словника німецьких неологізмів» спробували статистично змоделювати міру коливання активності нової лексики протягом десятиліття (Deutsches..., 2007, с. 7-8). Вони обстежили функціонування нових слів і відомих слів з новими значеннями в німецьких газетних текстах протягом 1996-2006 рр. Для кожного року формувалися самостійні річні корпуси текстів обсягом не менше 2 млн слів і на них для кожного неологізму обчислювалася абсолютна частота вживання. Для зіставлюваності статистичних показників до корпусів відбиралися тексти тих самих газет і тієї ж тематики, тобто в такий спосіб забезпечувалася однорідність річних вибірок. У статтях словника до кожного слова додано гістограму, або графік розподілу частоти вживання описуваного слова в текстах по роках. Завдяки цьому читачі словника, передусім дослідники мови, одержують картину зростання, спаду чи стабілізації активності вживання того чи того нового слова. Наприклад, гістограма до слова Euro засвідчує його місце на далекій периферії німецького газетного лексикону до 2002 р., коли євро було введено в грошовий обіг Німеччини як іiї нова державна валюта. Відтоді цей неологізм, як засвідчує гістограма, демонструє стабільність функціонування.

В інтерфейсі КТУМ запропоновано опцію укладення в інтерактивному режимі частотних словників для окремих текстів, авторів, тематичних розділів. Крім того, для вільного користування на порталі mova.info удоступнено низку частотних словників різних стилів мови, авторів, окремих творів. Матеріал до цих частотних словників можна добирати за абсолютною чи середньою частотою вживання лексем або їхніх окремих словоформ, частиною мови, класами морфем, буквеною структурою слів тощо. Словники дають уявлення про питому вагу й активність певних слів і тематичних груп лексики не лише в окремих стилях мови, а й в узусі або в ідіолекті окремого автора. Наприклад, частотний словник поезій Ліни Костенко, опублікованих у збірці «Вибране» (Київ, 1989), на 1603 різних іменники як найчастотніші подає слова люди, день, дуща, життя, час із абсолютною частотою вживання, відповідно, 25, 24, 23, 22,19 . Натомість словник сучасної публіцистики на 29441 іменник серед найуживаніших засвідчує слова витрата, асоціація, виступ, виставка, блок з абсолютною частотою їхнього вживання 970, 661, 601, 511, 466. Методику статистичного вимірювання ступенів продуктивності лек- 
сико-семантичних інновацій в українських та італійських медіатекстах за абсолютною й середньою частотою їхнього вживання запропонувала О. С. Макарова (Макарова, 2016). Проте для встановлення стабільної й набутої активності слів (активізації), як і їхніх утрачуваної (пасивізація) та втраченої активності, до уваги варто брати насамперед їхні якісні характеристики, функціональний потенціал слова в тексті й системі мови. Кількісні й статистичні показники лише підтримують «портрет слова», створений за його формальними й семантичними ознаками, підтверджують його активність і продуктивність у сучасному лексиконі й мовній діяльності спільноти.

Корпус дає змогу встановити реальні переваги у вживанні вже відомих варіантів слова, зокрема словозмінних. Наприклад, СУМ-1 (2012) і ГС (2011) як рівноправні, без обмежувальних ремарок, для слова серие подають варіантні форми родового відмінка множини сердець і сериь. Перевірка в КТУМ (n.d.) за двома найпоказовішими щодо вживання варіантних форм функціональними стилями мови - публіцистичним і художнім - дала таку картину: у публіцистичному стилі на 16650359 слововживань форма сердець має абсолютну частоту вживання 64, форма серць - 1; у художньому стилі на 22739060 слововживань форма сердець трапилася 129 разів, форма сериь - 3. У наукових текстах обсягом 2900956 слововживань співвідношення 8 до 1. Такі показники, навіть за незбігу обсягів підкорпусів текстів, сигналізують про необхідність у нових словниках нормативного, активного типу, принаймні, обмежувальних ремарок для форми серць на зразок менш уживана (рідко), уживана переважно в художніх текстах. Ці відомості доводять потребу простежити динаміку конкурування таких словозмінних форм у часі, просторі, текстах певного призначення, тематики, а це може призвести до необхідності розширення відповідних стильових підкорпусів корпусу й уточнення їхньої розмітки.

Однак корпус не надає можливості виявляти варіанти слів у текстах, оскільки для запиту їхні інтерфейси вимагають такого знання від користувача. Крім того, не забуваймо, що обсяг і склад інформації, одержуваної з корпусу, залежить від спектру вміщених у ньому текстів, їхньої розмітки. Якщо таких варіантів немає в текстах корпусу, а отже, і знання про них не закладено в розмітку текстів, то користувач і не зможе його видобути. Наприклад, тексти українських засобів масової інформації на сьогодні засвідчують три прикметники з основою інтернет-: інтернетний, 
інтернетовий і інтернетівський. У вже згаданому публіцистичному підкорпусі КТУМ по 2 рази трапилися прикметники інтернетний (зв'язок і образне суспільний планктон) і інтернетівський (сайт, самвидав), слово інтернетовий у ньому відсутнє. У науковому підкорпусі ці слова на сьогодні взагалі відсутні. У художньому підкорпусі лише 1 раз зустрівся прикметник інтернетівський (файл). Натомість, як доводять КФІ й сучасні ресурси Укрнету, ці прикметники не лише активно функціонують у мовній практиці, а й виказують семантичну диференціацію: інтернетний і інтернетовий мають суто відносне значення, а інтернетівський набуває якісно-відносного значення. Це дедалі виразніше виявляє їхня лексична сполучуваність (див. приклади вище). Така динаміка потребує відстежування за текстами різних стилів і аналізу, а отже, ці відомості, накопичувані в картотеці «портретів слів», дають імпульс для аналізу сучасних текстів і поповнення ними відповідних підкорпусів корпусу із семантичною розміткою в ньому таких прикметників-конкурентів. Розробники КТУМ нині активно працюють над створенням семантичної розмітки його текстів.

Картотека «портретів слів», ураховуючи системні характеристики слова, дає також орієнтири для перевірки за корпусом і текстами не лише окремих слів та словосполук, а й цілих поняттєвих груп і полів, що вербалізують у сучасній мові певне поняття чи окремі його аспекти. Так, із експресивно-оцінним значенням в українській, як і в інших слов'янських мовах, стабільно функціонують прикметники-кольороназви. Проте навіть у найновіших українських словниках далеко не повно відбито розвиток їхньої оцінної, метафоричної семантики. Наприклад, прикметник зелений у СУМ-I в 7-му його значенні з обмежувальною ремаркою політол. (термін політології) подано у функції іменника у формі множини (зелені) з дефініцією 'члени партії, яка бореться за екологічну чистоту довкілля' (СУМ-1, 2012, с. 366). Натомість сполуку Партія зелених подано чомусь до 2-го значення цього слова 'який стосується зелені, рослинності; створений, покритий рослинністю’. Матеріали КФІ засвідчують значно ширше вживання прикметника зелений у такому значенні як синоніма до означень чистий, екологічно чистий, незабруднений икідливими речовинами або який не забруднює шкідливими речовинами, порівн.: «зелений» автомобіль, «зелений бізнес», «зелене» будівництво, «зелена»енергетика. Уживання прикметника зелений у лапках беззастережно вказує на усвідомлення мовцями метафоричності цього значення. Саме тексти унаявнюють кон- 
курування таких номінацій з іншими ресурсами означення екологічно чистих об'єктів і технологій, порівн.: «зелена» енергетика й чиста енергетика, екоенергетика, біоенергетика, альтернативна енергетика, поновлювана енергетика; «зелене» паливо й біопаливо, альтернативне паливо, екологічне паливо (екопаливо), екологічно чисте паливо.

Отже, картотека й корпус становлять модель наших знань про, відповідно, номінацію й предикацію в мові, мовну систему й мовну діяльність спільноти. Для лексикографа вони являють собою необхідні інструменти укладання словника - «сполучені посудини», оскільки картотека в обговореному вище форматі «портрета слова» дає образ шуканої в тексті інформації про нього, а корпус як збалансована й кодифікована модель текстів дає уявлення про спектр уживання слова, характер його функціонування в тій чи тій сфері мовної діяльності суспільства або певного мовного осередка чи й окремого мовця. Водночас конкретна лексична картотека (картотека для створення певного словника) і корпус перебувають у ширшому просторі відомостей про мову: конкретна картотека $€$ варіантом фундаментальної, зведеної картотеки-скарбниці мови, а корпус становить вибірку за певними критеріями з усієї сукупності наявних на сьогодні текстів. Взаємодія картотеки й корпусу, їхнє взаєможивлення й взаємопідтримка закладають надійне підгрунтя для моделювання реальної картини складу та функціонування лексикону мови в словниках нового покоління.

\section{Скорочення}

WSJP - Żmigrodzki, P. (Comp.). (2015). Wielki słownik języka polskiego PAN: Zasady opracowania. Kraków. Retrieved April 1, 2017, from www.wsjp.pl/pobieranie/ Zasady_opracowania_WSJP.pdf

ГС - - Критська, В. І., Недозим, Т. І., Орлова, Л. В., Пуздирєва, Т. К., Романюк, Ю. В. (Comp.), \& Клименко, Н.Ф. (Еd.). (2011). Граматичний словник украӥнської літературної мови: Словозміна. Київ: Видавничий дім Дмитра Бураго.

КТуМ - Кориус текстів української мови [Електронний ресурс]. (n.d.). Retrieved April 1, 2017, from www.mova.info

СУМ-1 - Жайворонок, В. В. (Еd.). (2012). Словникукраїнськоїмови. Київ: ВЦ «Просвіта».

СУМ-20 - Русанівський, В. М. (Еd.). (2010). Словник української мови у 20 m. Київ: Наукова думка. 


\section{Література}

Quasthoff, U. (Ed.) (with Liebold, S., Taubert, N., \& Wolf, T.). (2007). Deutsches Neologismenwörterbuch: Neue Wörter und Wortbedeutungen in der Gegenwartssprache. Berlin: «Walter de Gruyter». https://doi.org/10.1515/9783110911138

Żmigrodzki, P. (Comp.). (2015). Wielki słownik języka polskiego PAN: Zasady opracowania [WSJP]. Kraków. Retrieved April 1, 2017, from www.wsjp.pl/pobieranie/Zasady_ opracowania_WSJP.pdf

Білодід, I. К. (Ed.). (1970-1980). Словник української мови [СУМ-11] (Vols. 1-11). Київ: Наукова думка.

Буцева, Т. Н. (2013). Неологическая служба русского языка. In Лексикология. Лексикограбия и корпусная лингвистика (рр. 93-98). Санкт-Петербург: Нестор-История.

Дарчук, Н. П. (2013). Комп’ютерне анотування украӥнського тексту: Результати і перспективи. Київ: Освіта України.

Жайворонок, В. В. (Ed.). (2012). Словник української мови [СУМ-1]. Київ: ВЦ «Просвіта».

Караулов, Ю.Н. (1981). Лингвистическое конструирование и тезаурус литературного языка. Москва: Наука.

Карпіловська, Є.А. (2004). Динаміка сучасної української мови в словниках нового покоління (проект серії словників нової української лексики). Українська мова, (3), 3-29.

Карпіловська, Є.А. (2006). Функціональний потенціал конкурентних моделей словотворення: Параметри стабільності похідних. In Функцыянальныя аспекты словаутварэння (рp. 92-101). Мінск: ВТАА «Права і эканоміка».

Карпіловська, Є. А. (Ed., Сomp.), Кислюк, Л. П., Клименко, Н. Ф., Критська, В. І., Пуздирєва, Т. К., \& Романюк, Ю. В. (Сотр.). (2013). Активні ресурси сучасної української номінації: Ідеограбічний словник нової лексики. Київ: ТОВ «КММ».

Корпус текстів украӥнської мови [КТУМ] [Електронний ресурс]. (n.d.). Retrieved April 1, 2017, from www.mova.info

Котелова, Н. 3. (1984). Предисловие. In Н. З. Котелова (Ed.), Новые слова и значения: Словарь-справочник по материалам прессы и литературы 70-х годов (рр. 3-12). Москва: Русский язык.

Критська, В. І., Недозим, Т. І., Орлова, Л. В., Пуздирєва, Т. К., Романюк, Ю. В. (Сотр.), \& Клименко, Н. Ф. (Еd.). (2011). Граматичний словник української літературної мови: Словозміна [ГС]. Київ: Видавничий дім Дмитра Бураго.

Лендау, С. I. (2012). Словники: Мистецтво та ремесло лексикографї (О. Кочерга, Trans.). Київ: «К.І.С.».

Макарова, О. С. (2016). Статистичне вимірювання ступеня продуктивності лексикосемантичних інновацій у сучасному медіа-дискурсі (на матеріалі італійської та української мов) (Автореферат дис. канд. філол. наук). Нац. педагог. ун-т ім М. П. Драгоманова, Київ. 
Німчук, В. В. (2012). Про сучасну українську тлумачну лексикографію. Українська мова, (3), 3-30. Пилипчук, Д. (2012). Болять мені загублені слова.... Мій додаток до першого тому Словника української мови у двадияти томах. Біла Церква: Білоцерків. книжк. фабрика.

Плунгян, В. А. (2009). Почему современная лингвистика должна быть лингвистикой корпусов [Електронний ресурс]. Retrieved from www. polit/ru/article/2009/10/23/corpus/

Русанівський, В. М. (Еd.). (2010). Словник української мови у 20 m. [СУМ-20] (Vol. 1). Київ: Наукова думка.

\section{Bibliography (transliteration)}

Bilodid, I. K. (Ed.). (1970-1980). Slovnyk ukraïns'koï movy [SUM-11] (Vols. 1-11). Kyïv: Naukova dumka.

Butseva, T. N. (2013). Neologicheskaia sluzhba russkogo iazyka. In Leksikologiia. Leksikografiia $i$ Korpusnaia lingvistika (pp. 93-98). Sankt-Peterburg: Nestor-Istoriia.

Darchuk, N. P. (2013). Komp'iuterne anotuvannia ukraïns'koho tekstu: Rezul'taty i perspektyvy. Kyïv: Osvita Ukraïny.

Karaulov, I. N. (1981). Lingvisticheskoe konstruirovanie i tezaurus literaturnogo iazyka. Moskva: Nauka.

Karpilovs'ka, I. A. (2004). Dynamika suchasnoï ukraïns'koï movy v slovnykakh novoho pokolinnia (proekt seriï slovnykiv novoï ukraïns'koï leksyky). Ukraïns'ka mova, (3), 3-29.

Karpilovs'ka, I. A. (2006). Funktsional'nyı̆ potentsial konkurentnykh modeleĭ slovotvorennia: Parametry stabil'nosti pokhidnykh. In Funktsyianal'nyia aspekty slovaŭtvarènnia (pp. 92-101). Minsk: VTAA "Prava i èkanomika."

Karpilovs'ka, I. A. (Ed., Comp.), Kisliuk, L. P., Klimenko, N. F., Kryts'ka, V. I., Puzdyrieva, T. K., \& Romaniuk, I. V. (Comp.). (2013). Aktyvni resursy suchasnoï ukraïns'koï nominatsiï: Ideohrafichnyı̆ slovnyk novoï leksyky. Kyïv: TOV "KMM.”

Korpus tekstiv ukraïns'koï movy [KTUM] [Electronic resource]. (n.d.). Retrieved from www. mova.info

Kotelova, N. Z. (1984). Predislovie. In N. Z. Kotelova (Ed.), Novye slova i znacheniia: Slovar'spravochnik po materialam pressy i literatury 70-kh godov (pp. 3-12). Moskva: Russkiǔ iazyk.

Kryts'ka, V. I., Nedozym, T. I., Orlova, L. V., Puzdyrieva, T. K., Romaniuk, I. V. (Comp.), \& Klymenko, N. F. (Ed.). (2011). Hramatychnyĭ slovnyk ukrä̈ns'koï literaturnoï movy: Slovozmina [HS]. Kyïv: Vydavnychyĭ dim Dmytra Buraho.

Lendau, S. I. (2012). Slovnyky: Mystetstvo ta remeslo leksykohrafï (O. Kocherha, Trans.). Kyïv: "K.I.S."

Makarova, O. S. (2016). Statystychne vymiriuvannia stupenia produktyvnosti leksykosemantychnykh innovatsĭ u suchasnomu media-dyskursi (na materiali italǐ̌s'kö̈ ta ukrä̈ns'koï mov) (Avtoreferat dys. kand. filol. nauk). Nats. pedagog. un-t im. M. P. Drahomanova, Kyïv.

Nimchuk, V. V. (2012). Pro suchasnu ukraïns'ku tlumachnu leksykohrafiiu. Ukraïns'ka mova, (3), 3-30. 
Plungian, V. A. (2009). Pochemu sovremennaia lingvistika dolzhna byt' lingvistikoŭ korpusov [Electronic resource]. Retrieved from www.polit/ru/article/2009/10/23/corpus/

Pylypchuk, D. (2012). Boliat' meni zahubleni slova...: Miŭ dodatok do pershoho tomu Slovnyka ukraïn'koï movy u dvadtsiaty tomakh. Bila TSerkva: Bilotserkiv. knyzhk. fabryka.

Quasthoff, U. (Ed.) (with Liebold, S., Taubert, N., \& Wolf, T.). (2007). Deutsches Neologismenwörterbuch: Neue Wörter und Wortbedeutungen in der Gegenwartssprache. Berlin: "Walter de Gruyter." https://doi.org/10.1515/9783110911138

Rusanivs'kyĭ, V. M. (Ed.). (2010). Slovnyk ukraïns'koï movy u 20 t. [SUM-20] (Vol. 1). Kyïv: Naukova dumka.

ZHaĭvoronok, V. V. (Ed.). (2012). Slovnyk ukraïns'koï movy [SUM-1]. Kyïv: VTS “Prosvita.”

Żmigrodzki, P. (Comp.). (2015). Wielki słownik jezzyka polskiego PAN: Zasady opracowania [WSJP]. Kraków. Retrieved from www.wsjp.pl/pobieranie/Zasady_opracowania_WSJP.pdf

\section{The role of "portraits of words" card index in the compiling of new generation dictionaries}

\section{Summary}

The article presents the concept of "portraits of words" card index as a necessary tool of the analysis of language changes for the compiling of dictionaries of new generation. Such card index contains information not only about the use of words in the texts of various functional styles, time, subject and purpose, but also about their systemic characteristics: paradigmatic, syntagmatic and epidigmatic (derivational and associative). The information about a word gathered in the card index of this type serves as guidelines for its verification in the corpus as well as in the various text databases, including online resources. It allows to check the use of new words, their spelling variations, development of their semantics, the course of their competition with other nominations of the same realities, processes or attributes in the texts. A "portraits of words" card index, as juxtaposed with the corpus and texts, signals the need to supplement the corpus with certain types of texts, as well as the need to change the annotation of its texts. This enables the preparation of verified materials for the compiling of new generation dictionaries. 


\section{Rola kartoteki „portretów słów” w tworzeniu słowników nowej generacji}

\section{Streszczenie}

W artykule przedstawiono koncepcję kartoteki „portretów słów” jako narzędzia analizy zmian językowych niezbędnego przy tworzeniu słowników nowego pokolenia. Kartoteka taka mieści w sobie informacje nie tylko o tym, jak słowo używane jest w tekstach o różnych stylach funkcjonalnych, z różnych okresów, o różnej tematyce i różnym przeznaczeniu, lecz także o jego charakterystykach systemowych: paradygmatycznych, syntagmatycznych i epidygmatycznych (słowotwórczych i asocjacyjnych). Informacje na temat słowa zgromadzone w takiej kartotece będą służyć jako swego rodzaju punkty orientacyjne przy weryfikacji występowania danego wyrazu w korpusie i bazach tekstów, zwłaszcza w internecie. Informacje te dają możliwość przeprowadzania porównań z tekstami pod kątem występowania nowych słów, wariantów ich pisowni, rozwoju ich semantyki, przebiegu ich konkurencji z innymi sposobami opisu tych samych realiów, procesów czy cech. Kartoteka tego rodzaju, w zestawieniu z korpusem i tekstami, sygnalizuje konieczność uzupełnienia korpusu o pewne rodzaje tekstów, a także potrzebę zmiany oznaczeń umieszczonych w korpusie tekstów - a tym samym pozwala na przygotowanie zweryfikowanego materiału wyjściowego do tworzenia słowników nowego pokolenia.

Keywords: language dynamics; lexicon; innovation; "portraits of words" card index; corpus; new generation dictionary

Słowa kluczowe: dynamika językowa; leksykon; innowacja; kartoteka „portretów słów”; korpus; słownik nowej generacji

Yevheniia Karpilovs'ka, Institute for the Ukrainian Language, National Academy of Sciences of Ukraine, Kyiv Correspondence: karpilovska@gmail.com

The preparation of this article was financed within the statutory activities of the Institute for the Ukrainian Language, National Academy of Sciences of Ukraine.

Competing interests: The author has declared she has no competing intererest. 